\title{
PLCE1 Gene
}

National Cancer Institute

\section{Source}

National Cancer Institute. PLCE1 Gene. NCI Thesaurus. Code C115067.

This gene is involved in both lipid metabolism and signal transduction. 